PLANTS PEOPLE

POSSIBILITIES

\title{
Some Additions to the Korean Flora
}

\section{Author(s): S. T. Dunn}

Source: Bulletin of Miscellaneous Information (Royal Botanic Gardens, Kew), Vol. 1912 , No. 2 (1912), pp. 108-109

Published by: Springer on behalf of Royal Botanic Gardens, Kew

Stable URL: http://www.jstor.org/stable/4104543

Accessed: 27-06-2016 03:31 UTC

Your use of the JSTOR archive indicates your acceptance of the Terms \& Conditions of Use, available at

http://about.jstor.org/terms

JSTOR is a not-for-profit service that helps scholars, researchers, and students discover, use, and build upon a wide range of content in a trusted digital archive. We use information technology and tools to increase productivity and facilitate new forms of scholarship. For more information about JSTOR, please contact support@jstor.org.

Royal Botanic Gardens, Kew, Springer are collaborating with JSTOR to digitize, preserve and extend access to Bulletin of Miscellaneous Information (Royal Botanic Gardens, Kew) 


\title{
IX.-SOME ADDITIONS TO THE KOREAN FLORA.
}

\author{
S. T. Dunn.
}

Our knowledge of the Korean flora has recently received an interesting addition from Dr. Ralph Mills, who has sent to Kew a collection of some 300 dried specimens of plants collected by him in the neighbourhood of Kangkai. Among them are represented two new species, a new variety, and several new records for the country. Kangkai, or Kangkyei as it is usually written on our maps, is situated near the northern boundary of the country in mountainous surroundings on the bank of the Tong Nai River, the principal affluent of the Yalu upon the Korean side. Its distance from both the east and west coasts is about 80 miles and from the Manchurian frontier 27 miles, and the fact that this part of Korea has scarcely been visited by botanists before adds greatly to the interest of the collection. Dr. Mills describes the mountains among which he gathered his specimens as clothed with vegetation from base to summit, and as bearing a markedly different flora on their northern slopes which drain into the Yalu system from that on the southern. The dividing ridges form indeed at this point a natural line of demarcation between the Manchurian and Korean climates and floras, the moist warm summer season being considerably shorter on the north side, while snow and ice are more frequently seen there and are more persistent. The actual divide follows the crest of the Paik-yek San, which passes from east to west about 30 miles south of the city, and as the much loftier range of the Pailk-tou San, the northern watershed of the Yalu basin, lies immediately to the north of it and between it and the greater part of Manchuria, it is a remarkable suggestion and one that will doubtless receive attention that it and not the northern divide forms the phytogeographical boundary between the two floras.

The following species and varieties are new to Korea :-

Euonymus alata, Thunb.

Prunus Maacki, Rupr.

Neillia Millsii, Dunn, sp. nov., N. sinensi, Oliv. affinis, calycis tubo breviore, ovulis duobus distincta.

Frutex cortice pallido scabro, ramis floriferis perulatis laxe hirsutis. Folia alterna, ovata, acuta, basi truncata, 4-5 cm. longa, grosse biserrata, nonnunquam fere triloba, papyracea, glabra, nervis 4-5paribus ; petioli 4-5 mm. longi, pubescentes; stipulae ovatae, 4-6 mm. longae, foliaceae. Racemi vel, ob ramos paucos breves, paniculi terminales, sessiles, 6-10 cm. longi. Flores approximati, 6-8 mm. longi, 3-4 mm. lati ; pedicelli $4 \mathrm{~mm}$. longi, ut raches, bracteaeque laxe pubescentes ; bracteae lineares, pedicello paullo longiores. Calyx campanulatus, extus glandulis pedicellatis vestitus, intus minute puberulus, dentibus 5 tubo bis brevioribus lanceolatis. Petala 5, ovata, alba, $3 \mathrm{~mm}$. longa, fauce inserta. Stamina ibidem, numerosa, petalis bis breviora, filamentis basi paullo dilatatis. Ovarium uniloculare, liberum, globosum, in stylo aequilongo angustatum, stigmate disciforme faucem paullo excedente. Ovula 2, a placenta parietali pendula.

Kangkai, Oct. 6th, 1909, R. Mills, 107, 
A handsome bush when in flower, growing abundantly on the hillsides from Kangkai down the Tong Nai to its junction with the Yalu and thence down to within a few miles of Antung in Manchuria. The fruit is described as green with soft prickles, appearing about midsummer.

Scolopia japonica, Max., var. parviflora, Dunn, var. nov. Flores $1 \cdot 5-1 \cdot 7 \mathrm{~cm}$. longi.

Kangkai, $R$. Mills, 216. A weed of waste ground.

Chenopodium glaucum, Linn.

Chloranthus japonicus, Sieb. et Zucc.

Humulus japonicus, Sieb.

Allium lineare, Linn.

Erythronium Dens-canis, Linn. Quite abundant in rich woods on the higher hills and also in the open ground. The flowers sometimes as much as 5 inches across. The species has not, hitherto, been recorded from the region embraced in Hemsley's Enumeration. Pl. China. R. Mills, 217.

Lilium concolor, Salisb.

L. elegans, Thunb.

Polygonatum verticillatum, All.

Tovaria japonica, Baker.

Lloydia triflora, Baker.

Arisaema japonicum, Blume.

Acorus Calamus, Linn.

Carex Millsii, Dunn, sp. nov. C. cryptostachyo, Brongn. affinis, foliis brevioribus, latioribus distincta.

Folia basalia anguste oblanceolata, acuta, ad basin gradatim angustata, ad $30 \mathrm{~cm}$. longa, $2-3 \mathrm{~cm}$. lata, papyracea, glabra, supra scaberula, basi vestigiis fibrosis cincta, nervis multis, 3 conspicuis, Scapi $3-4$, circiter foliis aequilongi, basi vaginis paucis brevibus vestiti. Spicae 5-6, distantes, saepissime singulae, androgynae, $1 \cdot 5-$ $2 \mathrm{~cm}$. longae, dimidio superiore masculo, inferiore foemineo, parte foeminea ovale viridula ; pedunculi spicis 2-plo longiores; bracteae pedunculis paullo breviores, ovatae, convolutae, pedunculum scapumque amplectentes, margine scariosae. Flores foeminei $6-9$; glumae ovatae, $s \mathrm{~mm}$. longae, acutae, margine scariosae ; utriculus aequilongus, ovalis, brevissime rostratus, glaber, paucinervis ; stylus trifidus.

Kangkai, R. Mills, 104, May 20th, 1910. In mossy ground among bushes on an isolated hill opposite the town.

\section{X.-MISCELLANEOUS NOTES.}

Mr. Charles Cumming Calder, B.Sc. of the University of Aberdeen, has been appointed by the Secretary of State for India in Council, on the recommendation of $\mathrm{Kew}$, Curator of the Herbarium of the Royal Botanic Gardens, Calcutta, in succession to Mr. W. W. Smith (K.B., 1907, p. 403), who has been transferred to the post of Assistant to the Regius Keeper of the Royal Botanic Garden, Edinburgh. 